\title{
Electronic product design and production of professional backbone teachers at the provincial level training program design and practice

\author{
Qiang Wang ${ }^{1, a}$, Ling Huang ${ }^{2, b}$ \\ ${ }^{1,2}$ College of Electrical and Information Engineering, Lanzhou University of Technology, Lanzhou \\ 730050, China \\ a wangqiang@lut.cn, b huangling@lut.cn
}

Keywords: Professional backbone teachers; Training program design; Vocational skills training; Vocational education

\begin{abstract}
The provincial training subject of electronic product design and production of professional backbone teachers through the feedback of market research and training school investigation screening. In the process of vocational skills training, vocational qualification certificate examination over the same period. For secondary vocational school teachers, in addition to vocational skills training, also need to improve their own quality, strengthen ethics construction, improve the humanities accomplishment. By the implementation of the training program, to make teachers has the exemplary role of the secondary vocational schools "double division type" professional backbone.
\end{abstract}

\section{Introduction}

According to " The Ministry of Education on Further Deepening the Reform of Secondary Vocational Education Teaching Several Opinions " spirit of the document[1], Combined with the Ministry of Education Issued by the "Secondary Vocational School Professional Directory"[2], To update the education teaching idea, improve teachers' comprehensive quality and practical ability as the key point, to cultivate a love of vocational education career, full of pioneering and innovative spirit, has the high vocational education quality and professional level of professional teachers, For the sustainable, rapid and healthy development of secondary vocational education personnel and technology provide strong guarantee.

\section{Training purpose}

In order to meet the needs of medium occupation school of electrical and electronic professional backbone teacher learning, improve the comprehensive ability of students knowledge, enhance students in new technology competitiveness, Combined with the students' needs and advice(As for the national vocational colleges vocational skills contest vocational skills training), Electronic product design and production of professional training from the perspective of the development and design, electronic product, debugging, product request, enable trainees to master the basic idea of electronic circuit design, electronic circuit fabrication method of electronic circuit debugging, the basic steps and skills. The whole process including electronic product design and production, according to a given project project should have certain practical and exploratory, new technologies and new methods. Including scheme choice, circuit design, circuit diagram drawing, protel software simulation, component selection, PCB board design, the production of printed circuit board, circuit welding, electronic products, installation and debugging. And aimed at the problems in the electronic product design and production, puts forward the methods and measures, finally, the performance of the electronic product testing. Through several typical examples of learning, inspire students thinking, broaden students' horizons, cultivate students' ability of analyzing and solving problems, to lay the solid integrated theory and practice foundation, achieve the result of "learning is for practical application".

Training will be relying on the 36th National Professional Skill Appraisal in Gansu Province, Strive to make the training teachers in the training to obtain the certificate of intermediate and 
advanced skill levels. This training aims to: Raise the level of teachers' professional theory and professional technology, with strong professional skills; Improve teachers' teaching methods and curriculum development ability, and can according to the law of new teaching in vocational education, the teaching idea, the courses of analysis and design of the system; Improve the level of teacher's vocational education theory, to renew the idea of vocational education, to promote teaching reform; Improve teacher education creation ability, life-long learning ability and comprehensive quality, make teachers have demonstration effect of secondary vocational school of "double division type" professional backbone [3,4,5].

\section{Training requirements}

Through training, training of teachers must meet the following basic requirements: Love of secondary vocational education career, conscientiously implement the party's education policy, With the spirit of innovation and reform of consciousness, Do both imparting knowledge and education to cultivate people, can be used as a model and example, serious working attitude and caring students; To use scientific methods to evaluate the test and analysis of various types of teaching good, is good at teaching practice sublimation as theory, summarizes some practical teaching methods, and gives its implementation; Is adapt to the requirements of the quality education of new education ideas and education concept, with high cultural accomplishment, rich and solid professional knowledge and theory, Good at constantly absorbing domestic and foreign professional technology of the latest scientific and technological achievements, constantly improve the level of secondary vocational school teachers' education teaching, improve teachers' ability of application level and the analysis and design, strengthen practical teaching ability, To improve teachers' professional knowledge structure, adapt to the needs of modern teaching; Make full use of all kinds of modern education technology in teaching, can adapt to modern network education and computer aided teaching[6,7].

\section{Teaching management measures}

\section{Teaching management}

Led by the college of electrical and information engineering and electronic information engineering department is responsible for the implementation of the supervision and inspection training program. In order to ensure the experiment, practice, design, production of practical training, in addition to teaching each school teachers should be involved in curriculum practice guidance work, during the period of training, each related experiment or training room is equipped with a professional teacher.

\section{Internship in enterprise}

Let the students learn and familiar with related enterprises advanced technology, production process, management system and culture, post standard, demand, and so on and so forth. Requires the students internship after writing a report.

\section{Visiting an enterprise}

Through a tour of the enterprise, the first is to let students understand present situation and the development of this professional in the industry, the second is to know the knowledge structure and the technical requirements of the industry, in order to make clear the purpose of training.

\section{Training content and plans}

Training time for 40 days, in three phases: The first stage, the main training content is the electronic product design and production of professional teaching theory research and practical ability. Take students as the main body, teacher as the leading factor, the theoretical study, practice and the combination of expert lectures training form, the combination of centralized lectures and panel discussion teaching method, and vocational education and professional electrical and electronic technology application research. Training students to master professional in the field of new knowledge, new technology, new process and new methods. The second stage, the main training 
content is the electronic product design and production practice. With ability as the standard, closely combining the reality of student work, is given priority to with face-to-face training base to carry out the research study and practical operation, through the scene view, practice means such as project training, improve the students' ability of electrical technology professional practice application, to meet the needs of the vocational education teaching work. The third stage, relying on the 36th national professional skill appraisal in Gansu Province, make the training teachers in the training to obtain the certificate of intermediate and advanced skill levels.

\section{Training arrangement}

Professional technical teaching and teaching theory is shown in Table 1 (80 hours):

Table 1 Professional technical teaching and teaching theory

\begin{tabular}{|c|c|c|c|c|}
\hline Course category & $\begin{array}{l}\text { Course } \\
\text { code }\end{array}$ & Course content & Teaching form & $\begin{array}{l}\text { Class } \\
\text { hour }\end{array}$ \\
\hline \multirow{2}{*}{$\begin{array}{l}\text { Electronic technology } \\
\text { theory and practice }\end{array}$} & A1 & Electronic product design technology & $\begin{array}{c}\text { Theory teaching/ } \\
\text { experiment }\end{array}$ & $20 / 12$ \\
\hline & A2 & PROTEL technology application & $\begin{array}{c}\text { Theory teaching/ } \\
\text { experiment }\end{array}$ & $20 / 12$ \\
\hline \multirow{4}{*}{ Expert lectures } & B1 & $\begin{array}{l}\text { China's vocational education present } \\
\text { situation and development thinking }\end{array}$ & Lectures & 4 \\
\hline & B2 & $\begin{array}{l}\text { Vocational School Teachers' Morality } \\
\text { Culture }\end{array}$ & Lectures & 4 \\
\hline & B3 & Computer practical new technology & Lectures & 4 \\
\hline & B4 & $\begin{array}{l}\text { Modern electronic technology design, } \\
\text { development trends }\end{array}$ & Lectures & 4 \\
\hline \multicolumn{2}{|l|}{ Total } & & & 80 \\
\hline
\end{tabular}

Professional knowledge and skills training is shown in Table 2(80 hours):

Table 2 Professional knowledge and skills training

\begin{tabular}{c|c|c|c|c}
\hline \multirow{2}{*}{ Course category } & $\begin{array}{c}\text { Course } \\
\text { code }\end{array}$ & Project & $\begin{array}{c}\text { Teaching } \\
\text { methods }\end{array}$ & $\begin{array}{c}\text { Class } \\
\text { hour }\end{array}$ \\
\hline \multirow{4}{*}{$\begin{array}{c}\text { Electronic product design } \\
\text { and production }\end{array}$} & C1 & Street light controller design & Training & 16 \\
\cline { 2 - 6 } & C2 & Sound and light control switch design & Training & 16 \\
\cline { 2 - 6 } & C3 & Infrared ray anti-theft alarm & Training & 16 \\
\cline { 2 - 6 } & C4 & Double guide the design of the alarm & Training & 16 \\
\hline \multicolumn{2}{c}{ Total } & Design of the electronic toys & Training & 16 \\
\hline
\end{tabular}

Professional skill appraisal is shown in Table 3(80 hours):

Table 3 Professional skill appraisal

\begin{tabular}{c|c|c|c|c}
\hline $\begin{array}{c}\text { Course } \\
\text { code }\end{array}$ & Training content & $\begin{array}{c}\text { Training } \\
\text { form }\end{array}$ & Training place & $\begin{array}{c}\text { Class } \\
\text { hour }\end{array}$ \\
\hline D1 & Theoretical guidance and practical intensive training & Operation & $\begin{array}{c}\text { School training } \\
\text { base }\end{array}$ & 40 \\
\hline D2 & $\begin{array}{c}\text { Actual operation to strengthen training and the } \\
\text { national professional skill appraisal }\end{array}$ & $\begin{array}{c}\text { Operation, } \\
\text { Test }\end{array}$ & Motor factory & 40 \\
\hline Total & & & & 80 \\
\hline
\end{tabular}

\section{Conclusion}

The provincial training subject of electronic product design and production of professional backbone teachers through the feedback of market research and training school investigation screening. In the process of vocational skills training, vocational qualification certificate examination over the same period. For secondary vocational school teachers, in addition to vocational skills training, also need to improve their own quality, strengthen ethics construction, improve the humanities accomplishment. In this regard, we also invite the relevant experts give each student a report, help you improve level and increase students awareness of vocational education. Our training have achieved good training effect, Got the training of students and 
educational departments fully affirmed.

\section{References}

[1] The Ministry of education and other seven ministries. Some opinions on Further Strengthening the work of the occupation education[EB/OL]. http:// baike.baidu.com/view/2994075.htm.

[2] Decisions of the State Council on vigorously develop vocational education [EB/OL]. http:// www. fzrxly.com/zjlt/5.htm.

[3] The CPC Central Committee and State Council. On deepening education reform and advancing quality education decision[EB/OL].http://www. people.com.cn/item/flfgk/gwy/jkww/j990613.html.

[4] State Board of Education. Principles opinion 21st century deepen the reform of vocational education [EB/OL].http://www.people.com.cn/item/flfgk/gwyfg/1998/206003199801.html.

[5] Xinhua news agency. The national medium and long-term education reform and development plan outline (2010-2020) [EB/OL].http://www.gov.cn/jrzg/2010-07/29/content_1667143.htm.

[6] "Modern vocational education system construction plan" (2012-2020) [EB/OL]. http://dzxhnisc.com/Article/ShowArticle.asp?ArticleID=780

[7] China set 2015 primary development goal of modern vocational education[EB/OL]. http:// news. xinhuanet.com/2014-06/24/c_1111276944.htm 